politica, 38. årg. nr. 3 2006, 298-316

\title{
Jørgen Dige Pedersen
}

\section{Indien møder globaliseringen}

\begin{abstract}
Indien tiltrækker sig i disse år stor opmærksomhed, fordi landet økonomisk set har klaret sig ganske godt. En væsentlig del af baggrunden for den gunstige udvikling skal findes i de $\varnothing$ konomisk-politiske foranstaltninger, som den indiske regering har iværksat i samspil med det indiske erhvervsliv, der var vokset frem under den tidligere beskyttelsesstrategi. Der er dog også flere mindre succesrige udviklingstræk, og globaliseringen har haft sine sociale skyggesider. Det indiske udviklingsforløb udfordrer på flere områder etablerede udviklingsteoretiske positioner, og det kan af denne grund være med til at nuancere fremherskende opfattelser af, hvorledes udviklingslandene bedst tackler globaliseringens udfordringer.
\end{abstract}

Indien er i de senere års internationale debat blevet tildelt en ny rolle. Hvor landet tidligere blev portrætteret som et fattigt og problemfyldt uland, fremstår det i dag som et stort og dynamisk land, der forventes snart at indtage en rolle $\mathrm{i}$ verden, som dets størrelse berettiger til. Det er især den høje økonomiske vækst og landets fremtrædende placering inden for videnstunge erhvervsområder, der har vakt opmærksomhed. Dette skift i opfattelsen af landet kan i sig selv ses som et resultat af en vellykket deltagelse i globaliseringen, og det er derfor interessant at se på den måde, hvorpå denne succes er blevet opnået. Indiens udvikling har altid været stærkt præget af den statslige politik, og artiklen vil derfor fokusere på den indiske stats strategier for succesrig deltagelse i globaliseringen med hovedvægten på de sidste $15-20$ års politik. ${ }^{1}$

\section{Globaliseringens udfordringer og muligheder}

Globalisering bredt forstået omfatter en lang række forandringsprocesser med formodet global rækkevidde spændende fra intensiverede $\emptyset$ konomiske interaktioner over migrationsprocesser samt sociale og kulturelle forandringer til miljømæssige processer (Held et al., 1999). I denne artikel vil globalisering imidlertid primært henvise til forandringerne i den internationale $\emptyset$ konomi, inklusive de dertil knyttede ændringer i dens rammebetingelser. Mere konkret vil betegnelsen $\emptyset$ konomisk globalisering blive anvendt om intensiveringen af de internationale handelsmæssige og finansielle forbindelser og om de ændringer i rammebetingelserne for internationalt $\varnothing$ konomisk samkvem, der er kommet til udtryk gennem de internationale handelsforhandlinger, som i første omgang resulterede i skabelsen af verdenshandelsorganisationen, WTO, og i anden omgang er blevet videreført inden for denne organisations rammer. For nærmere at karakterisere nogle af de udfordringer, som globaliseringen forstået på denne måde har bevirket for et land som Indien, vil der desuden blive knyttet an til nogle betragtninger omkring aktuelle ændringer i den globale kapitalismes karakter, især i de førende kapitalistiske lande.

Transformationen i de mest fremskredne kapitalistiske økonomier har sit tyng- 
depunkt i en række teknologiske og organisatoriske nybrud, som af nogle teoretikere beskrives som en overgang fra fordisme til post-fordistiske produktionsmetoder med tilhørende nye samfundsmæssige reguleringsmekanismer (Hoogvelt, 1997). Andre betegner det som en overgang til et nyt "tekno-økonomisk paradigme" karakteriseret ved en gennemgribende anvendelse af mikroelektronik og informationsteknologi og væk fra de hidtil dominerende fordistiske samlebåndsindustrier (Pérez, 2001). Der tales også om fremkomsten af en ny, mere vidensintensiv eller vidensbaseret $\varnothing$ konomi (OECD, 1996). Man kan med udgangspunkt i disse betragtninger sige, at vi i dag er vidne til nogle omfattende $\varnothing$ konomiske forandringsprocesser, som både indeholder et globaliseringsaspekt og et transformationsaspekt (Hoogvelt, 1997). Globaliseringen stiller ikke mindst udviklingslandene over for en række udfordringer, hvor en af de væsentligste vil være at finde en fordelagtig placering i forhold de ændrede økonomiske vilkår, som transformationsprocessen, eller det økonomiske paradigmeskift, indebærer. Ifølge Carlota Pérez, som er en af de få forskere, der har forsøgt at vurdere udviklingslandenes muligheder, er der lidt forenklet to mulige strategier i en sådan transformationsperiode (2001). Den ene mulighed er at fors $\emptyset$ ge at industrialisere gennem at overtage eller invitere de "gamle" industrier, som vil være under udfasning i de rige industrilande. Problemet kan her være, at det vil kræve store investeringer, og at profitabiliteten vil være relativt lav, blandt andet fordi der vil være tale om velkendte og udbredte produktionsteknologier. Den anden mulighed er at forsøge at "hoppe med på vognen" ved at satse på udvikling af og deltagelse i de nye produktionsaktiviteter, som følger af de nye teknologier og det nye produktionsparadigme. Her vil fortjenesten kunne blive høj, og der vil være store dynamiske fordele, men samtidig kan der være problemer med at skaffe sig adgang til den nødvendige teknologi. I virkelighedens verden vil der naturligvis være tale om et blandingsforhold mellem de to strategier og de to idealtyper af produktionsparadigmer, og man kan forestille sig, at de optræder i forskellige sekvenser. Samlet giver disse betragtninger over mulige dynamiske virkninger af de to yderpunkter dog et nyttigt grundlag, når man skal karakterisere konkrete globaliseringsstrategier og vurdere deres $\emptyset$ konomiske fremtidspotentiale.

Globaliseringen kan - alt efter betragtningsmåde - tidsfæstes på forskellig vis, men set fra udviklingslandenes position kan man med rimelighed datere den aktuelle globalisering til perioden efter den første oliekrise, dvs. starten/midten af 1970 'erne. Den pludselige overførsel af meget store finansielle ressourcer til de olieproducerende lande og den efterfølgende recycling af disse midler igennem store udlån til mange udviklingslande lagde grunden til 1980'ernes gældskrise. ${ }^{2}$

Gældskrisen blev på den ene side udløst af renteforhøjelser i USA, Storbritannien og Vesttyskland, som i løbet af kort tid bevirkede, at mange udviklingslande - startende med Mexico i august 1982 - måtte indstille afbetalingerne på deres udlandsgæld. Gældskrisen var således et udtryk for en globaliseringsmekanisme på det finansielle område, og den efterfølgende bølge af økonomiske liberaliseringspolitikker, som Verdensbanken og Den Internationale Valutafond påtvang et meget stort antal gældsplagede udviklingslande op gennem 1980'erne, 
betød på den anden side en yderligere uddybning af den økonomiske globalisering.

Den største udfordring, som den stigende globalisering frembyder for udviklingslandene, herunder Indien, består naturligvis i at maksimere mulighederne og samtidig minimere farerne. På den ene side vil landene således prøve at tiltrække finansielle ressourcer, teknologi og viden fra resten af verden og samtidig hermed fors $\emptyset$ ge at udnytte de nye muligheder for at afsætte egne produkter og indtjene valuta, som den stadig lettere adgang til globale markeder også frembyder. På den anden side vil landene prøve at imødegå globaliseringens farer dels risikoen for at blive marginaliseret i den globale $\emptyset$ konomi, dels risikoen for, at den lokale $\emptyset$ konomi overtages af udenlandske kræfter eller underordnes global kontrol, så de må opgive udsigten til en selvbærende økonomisk udvikling. Endelig ligger der en udfordring $i$ at medvirke til at udforme de globale institutionelle rammer og regler, som globaliseringen foregår under, så disse i mindst muligt omfang indsnævrer handlerummet for landenes udviklingsstrategier.

I det følgende vil jeg beskrive, hvorledes den indiske stat har forsøgt at tackle disse udfordringer i perioden siden 1980. Hovedfokus er især på den ikke-agrare $\emptyset$ konomi, først og fremmest industrisektoren, da landbrugssektoren både på globalt plan og nationalt i Indien har været forholdsvis afsondret fra den globale økonomi, og dermed indtil nu kun i mindre grad har været berørt af globaliseringen.

\section{Den indiske stats strategi over for globaliseringen}

Indledningsvis er det vigtigt at bemærke, at den indiske stat siden uafhængigheden generelt har foretaget ganske omfattende indgreb i økonomien. Samtidig hermed har den indiske økonomi dog grundlæggende været kendetegnet ved at være en privatkapitalistisk $\emptyset$ konomi, hvor de afgørende $\emptyset$ konomiske beslutninger altid er blevet truffet af private virksomheder. Dette indebærer, at både den generelle indiske udviklingsstrategi og den nyere strategi over for globaliseringen er blevet udformet i et samspil mellem staten og de private virksomheder, og at en stor del af gennemførelsen har påhvilet private virksomheder.

Den traditionelle indiske udviklingsstrategi, som den blev udformet i årene lige efter uafhængigheden fra britisk kolonistyre, bestod af en vidtgående beskyttelse imod påvirkninger fra den internationale økonomi kombineret med en stærkt statsstyret satsning på industrialisering. Self-Reliance blev den alment anerkendte betegnelse for målet med strategien, som ud over en satsning på importsubstitutions-industrialisering indebar betydelige restriktioner på omfanget og karakteren af udenlandske investeringer samt opbygning af en stor statsligt ejet industrisektor på områder, der blev vurderet som vigtige og liggende uden for den private indiske industris formåen (Degnbol-Martinussen, 2001). Det var denne strategi, som i løbet af 1980'erne i stigende grad blev udfordret af globaliseringen, og som på afg $\varnothing-$ rende vis blev ændret med iværksættelsen af de omfattende økonomiske reformer i 1991. Det er vigtigt at bemærke, at mens den stærkt statsstyrede udviklingsstrategi generelt ikke resulterede i høje vækstrater, så blev der i ly af den statslige beskyttelses- og udviklingspolitik opbygget et usædvanlig stærkt, kompetent og indflydelsesrigt lokalt erhvervsliv spændende over et meget bredt felt af $\emptyset$ konomiske 
aktiviteter. Det lokale erhvervsliv var også et meget væsentligt grundlag for de udviklingspolitiske nyordninger, som har udgjort det indiske svar på globaliseringens udfordringer. Den indiske strategi over for globaliseringen kan tidsmæssigt opdeles i de tidlige - forsigtige - nyorienteringer i 1980'erne og så de mere omfattende reformer fra $1991 \mathrm{og}$ fremefter.

\section{Forsigtig liberalisering i 1980'erne}

Allerede fra slutningen af 1970'erne skete der to nyorienteringer i den indiske regerings udviklingspolitik. Den ene nyorientering vedrørte den statslige kontrol med $\varnothing$ konomien. I flere kommissionsrapporter fra slutningen af 1970 'erne og begyndelsen af 1980'erne blev det således anbefalet at begynde langsomt at afvikle de statslige kontrolmekanismer, både restriktionerne på udenrigshandelen og det omfattende system med statslige investeringstilladelser (Marathi, 1986; Wadhva, 1994; Degnbol-Martinussen, 2001). I løbet af 1980'erne skete der da også en gradvis liberalisering, især på det industripolitiske område, først og fremmest efter at den nye regering under Rajiv Gandhi havde konsolideret sin magtposition i 1985 og havde proklameret, at Indien nu skulle bringes ind i det 21 . århundrede (Patel, 1987). De generelle liberaliseringer summerede i den sidste ende dog kun op til mindre modifikationer af et overordnet system, som fik lov til at fortsætte, blandt andet på grund af modstand fra de mange velerhvervede interesser, som kontrolsystemet også havde skabt (Harriss, 1987; Kohli, 1989). I nogle få sektorer skete der dog reelle ændringer. Inden for den vigtige tekstilindustri, som blandt andet på grund af sin beskæftigelsesmæssige rolle har stor betydning, blev en række hidtidige restriktioner afskaffet. De store tekstilvirksomheder fik således bedre muligheder for at udvide deres aktiviteter og for at indkøbe mere avanceret udenlandsk produktionsudstyr. Den anden sektor, som oplevede en omfattende liberalisering, var it-industrien - først og fremmest computerindustrien - men også den begyndende software-"industri”". Det var ganske vist lykkedes den indiske regering gennem en omfattende beskyttelsespolitik at opbygge en indenlandsk computer- og elektronikindustri, men på grund af den hastige udvikling internationalt haltede de indiske virksomheder konstant teknologisk bagefter til skade for både udbredelsen og brugen af elektroniske produkter. I 1984 åbnede man derfor op for import af udenlandske komponenter og færdige computere, og det blev tilladt udenlandske virksomheder at investere i branchen. Alt dette bevirkede et mærkbart teknologisk løft og et betydeligt fald i priserne, og begge dele fremmede naturligvis udbredelsen af it-teknologien. Set i bakspejlet er det samtidig værd at bemærke, at adgangen til nyt og avanceret computerudstyr var med til at lægge grunden til den indiske software-industri. Ændringerne i den indiske industripolitik er, set i forhold til 1990'ernes politik, blevet karakteriseret som en bevægelse i mere pro-business retning, som dog samtidig ikke for alvor betød en ændring i pro-market retning (Kohli, 2006). Betegnelserne dækker over, at politikændringerne primært betød lempelser for de allerede etablerede indiske virksomheder, men at de ikke i væsentligt omfang gav adgang for nye konkurrenter - hverken nyetablerede indiske virksomheder eller udenlandske virksomheder. 
Den anden udviklingspolitiske nyorientering, som blev påbegyndt i 1980'erne, bestod $\mathrm{i}$ et aktivt indtog på de internationale lånemarkeder. Tidligere havde Indien næsten udelukkende benyttet udenlandsk finansiering i form af koncessionelle lån fra de officielle bilaterale og multilaterale bistandsorganisationer. Denne tilbageholdenhed havde sandsynligvis medvirket til en dæmpning af den økonomiske vækst, men den positive side var, at Indien på grund af sin forsigtighed undgik at blive ramt af den internationale gældskrise. Positionen som ikke-gældsplaget land bevirkede i 1980'erne, at Indien blev opfattet som et ganske attraktivt land at udlåne penge til, og det benyttede den indiske regering sig af og begyndte at optage store kommercielle og - modsat bistandsmidlerne - ubundne lån i udlandet. Udlandslånene stimulerede givetvis den økonomiske vækst, men bagsiden var naturligvis, at udlandsgælden og afbetalingerne på den også voksede dramatisk. I slutningen af 1980'erne udgjorde de årlige afbetalinger således mere end 30 pct. af eksportindtægterne - tre gange så meget som ved årtiets begyndelse (World Bank, 2006).

Golfkrigen, stigende oliepriser og faldende indtægter fra gæstearbejdere ansat i mellemøstlige lande bevirkede i 1990-91, sammen med nervøse udlandsinderes tilbagetrækning af deres investerede midler, at Indiens forøgede $\varnothing$ konomiske sårbarhed udviklede sig til en alvorlig økonomisk krise. Det var denne $\emptyset$ konomiske krise, som ydermere faldt sammen med politisk turbulente år med hyppige regeringsskift kulminerende med mordet på Rajiv Gandhi i maj 1991, der blev anledningen til en radikal nyorientering af den indiske udviklingspolitik. Den nytiltrådte mindretalsregering ledet af Kongrespartiet bekendtgjorde således i juli 1991 en række ændringer af den hidtidige udviklingspolitik, som af samtidige iagttagere blev betragtet som det mest dramatiske nybrud på det $\emptyset$ konomiske område i det selvstændige Indiens historie.

\section{0'ernes politik: åbenhed og konkurrence}

Den nye $\varnothing$ konomiske politik bestod i første omgang af to elementer. Det ene var en række kriseforanstaltninger, hvis formål var at stabilisere økonomien. De bestod blandt andet af en devaluering af den indiske valuta, rupeen, over to omgange med i alt ca. 20 pct. og en række besparelser, som havde til formål at reducere underskuddet på statsbudgettet. Mere interessant var det andet element. Det bestod nemlig af en næsten fuldstændig ophævelse af statskontrollen med private investeringer, en lempelse af monopollovgivningens begrænsninger på de store virksomheders aktiviteter samt liberalisering af reglerne for udenlandske investeringer og for import af udenlandsk teknologi, og endelig åbnede regeringen op for privatisering af statslige virksomheder og afskaffede disse virksomheders særrettigheder inden for en række sektorer (Government of India, 1991). Samlet betød disse nye tiltag en nærmest total afskaffelse af de bærende elementer i den hidtidige indenlandske udviklingspolitik, og i tillæg hertil kom så en række tiltag, som pegede i retning af en stadig mindre statslig kontrol med udenrigshandelen, først og fremmest gennem lempelser i importreguleringen og reduktioner af en række toldsatser. Overordnet set betød den nye $\emptyset$ konomiske politik en langt stærkere satsning på den private sektor, på markedsmæssige 
incitamentsstrukturer og på en integration i den globale økonomi. Globaliseringen var for alvor kommet til Indien.

For mange iagttagere kom denne udviklingsstrategiske kovending overraskende, og det blev da også af kyndige iagttagere forudsagt, at den nye politik ikke ville være politisk holdbar på længere sigt (Manor, 1995; Joshi and Little, 1997). Indiens demokratiske politiske system giver oppositionelle grupper gode muligheder for at komme til orde, og modstanden mod den nye politik manifesterede sig da også ganske hurtigt. Et godt eksempel på dette er, at en række græsrodsorganisationer og akademikere med tilknytning til den politiske venstrefløj siden 1993 har udgivet et årligt "Alternative Economic Survey" som et modstykke til regeringens årlige $\emptyset$ konomiske oversigt. ${ }^{3}$ Partierne uden for regeringskoalitionen har da også løbende kritiseret regeringens $\emptyset$ konomiske politik, men samtidig er det bemærkelsesværdigt, at den økonomiske reformpolitik er blevet fortsat uanset skiftende regeringskoalitioner, som op igennem 1990'erne efter tur har omfattet alle betydende politiske fløje, startende med Kongrespartiet i perioden 199196, efterfulgt af centrum-venstrefløjen 1996-1998 og senere centrum-højrefløjen 1998-2004. ${ }^{4} \mathrm{Og}$ i dag fortsættes reformpolitikken af en flerpartikoalition omkring Kongrespartiet, der har den politiske venstrefløj med blandt andre de indiske kommunistpartier som parlamentarisk støtte. ${ }^{5}$

Videreførelsen af reformpolitikken efter 1991-kovendingen har dog været ganske forsigtig og gradvis. ${ }^{6}$ Der er blevet lempet mere og mere på den statslige kontrol med den indenlandske $\emptyset$ konomi, med udenrigshandelen og med udenlandske investeringer, men på en række områder har den indiske stat dog bibeholdt en væsentlig rolle, og der er også blevet opbygget nye institutioner med det formål at sikre en vis regulering af de markedsmæssige mekanismer. Eksempler på en fortsat stærk statslig rolle finder man i reguleringen af betalingsbalancens kapitalposter, i den finansielle sektor, hvor de statslige banker fortsat spiller den dominerende rolle, og i opretholdelsen af de store statsvirksomheder. På trods af gentagne erklæringer om privatisering af tabsgivende statsvirksomheder er det meget begrænset, hvad der er sket på området. Først i år 2000 skete der et direkte frasalg af en statsvirksomhed (en brødfabrik), mens de øvrige tiltag på området mest har haft karakter af frasalg af mindre aktieposter i udvalgte statsejede selskaber uden at rokke ved den overordnede statslige kontrol. En af grundene til den meget begrænsede privatisering er formentlig den store modstand imod det blandt de velorganiserede og politisk indflydelsesrige arbejdere i statsvirksomhederne. Modstanden fra de organiserede arbejdere er formentlig også grunden til, at de planlagte arbejdsmarkedsreformer, som blandt andet ville medføre mindre jobsikkerhed, heller ikke er blevet til noget endnu. Efter årtusindeskiftet har der dog været flere direkte frasalg af statsvirksomheder. I $2001 \mathrm{blev}$ de sidste kvantitative restriktioner på importen afskaffet. Der er også blevet åbnet yderligere op for udenlandske investeringer, og den hidtidige liberale indiske patentlovgivning er blevet strammet op, så der ydes større beskyttelse af patentindehaverne. Flere af de seneste liberaliseringstiltag må ses som en følge af de krav, som medlemskabet af WTO stiller.

Opbygningen af nye politisk udpegede, men ellers uafhængige regulerende 
institutioner har især fundet sted inden for den finansielle sektor, hvor behovet for regulering af blandt andet aktiemarkederne blev tydeligt efter flere tilfælde af meget store finansskandaler med omfattende spekulation og svindel i forbindelse med større børstransaktioner. Også inden for den hurtigt voksende telekommunikationssektor er det blevet den foretrukne form for regulering, og det overvejes også inden for den hurtigt voksende indenlandske luftfart.

\section{Specifikke udfordringer}

Som nævnt $\mathrm{i}$ indledningen frembyder globaliseringens sammenfald med overgangen til nye vidensintensive produktionsformer særlige problemer for mindre udviklede lande, som åbner op for international konkurrence. Blandt kritikerne både af de forsigtige liberaliseringstiltag i midten af 1980'erne og af den nye $\varnothing$ konomiske politik fra 1991 blev det således fremhævet, at indiske virksomheder ikke ville være i stand til at klare konkurrencen med udenlandske virksomheder. Man risikerede derfor, at den indiske industri ville blive overtaget af udenlandske konkurrenter, som både teknologisk og finansielt ville være langt stærkere end indiske virksomheder. Denne frygt var også udbredt blandt indiske industrifolk, og op igennem 1990'erne protesterede repræsentanter for dele af erhvervslivet da også imod elementer i den nye økonomiske politik, som de mente gav urimelige fordele til de udenlandske firmaer. Den indiske regering var dog ganske lydhør over for erhvervslivets indvendinger og foretog flere justeringer i politikken, som reelt tilgodeså de indiske virksomheder. Et tydeligt eksempel herpå var en regel, der blev indført i 1998, som gav de indiske partnere i eksisterende joint ventures vetoret, såfremt deres udenlandske samarbejdspartnere $\emptyset$ nskede at investere i nye projekter inden for relaterede brancher. Reglen blev ophævet i 2005.

Et centralt, men også problematisk område for reformpolitikken har været politikken i forhold til den hastige teknologiske udvikling. Det har hele tiden været erkendt, at en vellykket inddragelse i den globale økonomi ville kræve dels en teknologisk opgradering af indisk industri, dels en vedvarende indsats inden for forskning og udvikling. Åbningen over for udenlandske investeringer var til dels et resultat af denne erkendelse, men det var samtidig opfattelsen, at en $\emptyset$ get konkurrence ville få indiske virksomheder til selv at investere mere i forskningsog udviklingsaktiviteter (Government of India, 1991). Denne opfattelse af, at markedet ville give virksomhederne tilstrækkeligt incitament til en forøget teknologisk indsats, har formodentlig været medvirkende til, at den indiske stat i den første del af 1990'erne kun i begrænset omfang gjorde en indsats for at fremme den teknologiske udvikling. Fra 1996 og fremefter har man dog udvidet de forskellige skattemæssige incitamenter til forskningsaktive virksomheder. Inden for udvalgte vidensintensive industrigrene, først og fremmest it-industrien, har den indiske stat ydet en betydelig støtte ved at etablere den nødvendige kommunikationsinfrastruktur, udvide uddannelsessystemets kapacitet på området og etablere forskellige eksportfremmende foranstaltninger.

Et tredje område, som er kommet til at spille en stadig større rolle for Indien og for den måde, hvorpå landet har valgt at tackle globaliseringen, er forholdet til WTO-regelsættene og til de fortløbende forhandlinger inden for organisationen. 
Indien havde oprindelig i samarbejde med Brasilien modsat sig mange af de elementer, som senere kom til at indgå i WTO-systemet (McDowell, 1994). Frem til slutningen af 1980'erne fastholdt begge lande således, at områder som serviceydelser, investeringsregler og spørgsmål om intellektuelle ejendomsrettigheder ikke hørte hjemme på dagsordenen for de internationale handelsforhandlinger under GATT, og de gik kun modstræbende med til at forhandle disse nye emner. Alliance mellem Brasilien og Indien gik imidlertid i opløsning, og begge lande holdt lav profil op til dannelsen af WTO i 1995. Det var først i slutningen af 1990'erne, hvor omfanget af WTO-forpligtelserne for alvor begyndte at gå op for både den indiske regering og det indiske erhvervsliv, at Indien begyndte at føre en mere aktiv og velforberedt politik inden for WTO. Et af midlerne i denne aktive politik var gendannelsen af alliancen med Brasilien og en lang række andre ulande. Herved er det lykkedes at opnå langt større indflydelse på forløbet og resultaterne af de globale forhandlinger. Et andet element i Indiens mere aktive politik består i en meget intensiv udnyttelse af WTO-reglernes muligheder for handelspolitiske "forsvarsforanstaltninger", som eksempelvis anti-dumping foranstaltninger. Indiens anvendelse af denne type tilladte handelsrestriktioner overgås kun af USA, og Indien har også i stort mål anvendt WTO's procedurer for at rejse sager om handelshindringer. ${ }^{7}$

\section{Resultaterne: Indiens betingede succes}

Et overordnet indtryk af, hvorledes Indien har klaret globaliseringens udfordringer, kan man få ved at betragte den samlede økonomiske vækst. Som det ses af figur 1, har Indien siden starten af 1980'erne formået at opretholde pæne økonomiske vækstrater, dog afbrudt af periodiske nedture. Det bemærkelsesværdige i det indiske vækstforl $\varnothing \mathrm{b}$ er imidlertid, at de omfattende $\varnothing$ konomiske reformer i 1991 tilsyneladende ikke har haft afgørende konsekvenser for den økonomiske vækst, som stort set er blevet opretholdt på samme niveau. ${ }^{8}$ Man kan dog med stor sikkerhed sige, at den indiske $\varnothing$ konomi ikke som frygtet af mange er brudt sammen i mødet med globaliseringen, men derimod har klaret sig væsentlig bedre end andre fattige lande i tilnærmelsesvis samme situation. Efter årtusindeskiftet lader det endda til, at væksten er tiltaget med årlige vækstrater de seneste tre år på omkring 8 pct. Det er blandt andet disse vækstrater, som har ført til de mange spekulationer om Indien som en kommende $\emptyset$ konomisk stormagt.

Væksten i den indiske økonomi har især været båret af servicesektorerne og af industriel fremstillingsvirksomhed, mens landbruget har fortsat tabt terræn i forhold til økonomiens andre sektorer. ${ }^{9}$ Selv om industrien har oplevet høje vækstrater, blev den samlede vækst i løbet af 1990'erne dog mindre end i 1980'erne, og først efter år 2000 synes der at være tale om en stabil høj vækst. Væksten har dog samtidig været nogenlunde jævnt fordelt på de forskellige industrielle sektorer, således at den i forvejen ganske diversificerede industristruktur er blevet opretholdt nogenlunde intakt, dog med en tendens til, at det er produktionen af varige forbrugsgoder - formentlig rettet imod den voksende indiske middelklasse - som er vokset hurtigst. Der har også været en tendens til, at de undersektorer, som af OECD regnes for de mest højteknologiske, har fået øget betydning, men 
Figur 1. Årlig vækst i bruttonationalproduktet, 1970/71-2005/06

Pct.

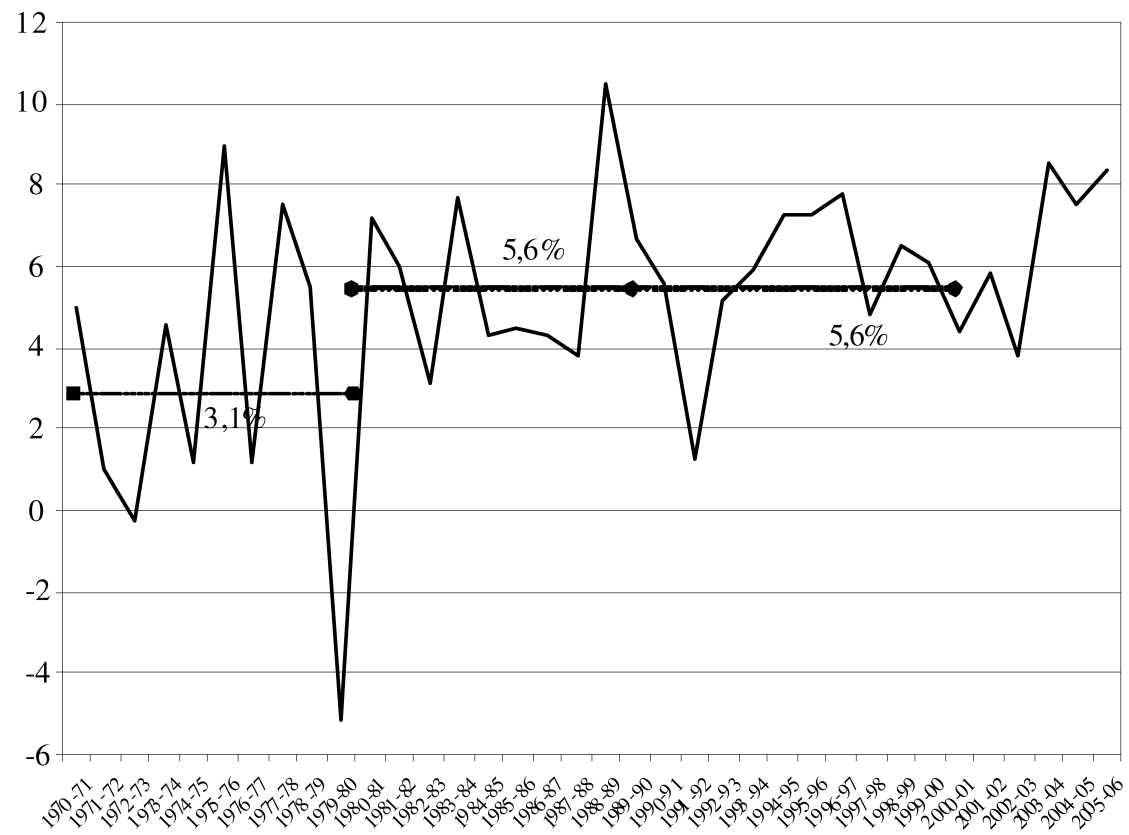

Note: De stiplede linjer angiver den gennemsnitlige vækstrate for hvert årti (1970/ 71-80/81, 1980/81-1990/91, 1990/91-2000/01).

Kilde: Central Statistical Organisation (http://mospi.nic.in).

de udgør dog stadig en meget begrænset del af den samlede industrisektor. ${ }^{10}$ Indsatsen på forsknings- og udviklingsområdet fra de indiske virksomheders side har dog været skuffende, specielt set i lyset af regeringens forventninger. Det er ganske vist et vanskeligt målbart område, men man kan konstatere, at alle oplysninger tyder på, at virksomhedernes udgifter til disse formål har udgjort en konstant andel af omsætningen, og at specielt de statslige virksomheder har reduceret deres indsats. ${ }^{11}$ Antallet af rene tekniske samarbejdsaftaler med udenlandske virksomheder har samtidig været faldende fra starten af 1990'erne, mens antallet af aftaler, som indebærer en grad af finansiel udenlandsk kontrol, har været stigende. Da de sidstnævnte formentlig også indeholder teknologiske elementer, blot under stærkere kontrol fra den udenlandske virksomheds side, peger meget på, at indisk industri har forøget sin import af udenlandsk teknologi, mens den hjemlige teknologiudvikling er blevet nedprioriteret. Nettoeffekten har dog uden tvivl været en betydelig modernisering og teknologisk opgradering, som har bragt indisk industri væsentlig nærmere den førende internationale standard, og der findes eksempler på virksomheder, som klart har øget deres indsats (Forbes, 
2002). Det omfatter også en stigende anvendelse af informations- og kommunikationsteknologien, og antallet af indiske virksomheder, som betragtes som værende i "verdensklasse", er blevet forøget (Ghoshal et al., 2001). ${ }^{12}$ Det bedste vidnesbyrd på, at indiske virksomheder har gjort betydelige fremskridt, er den meget markante stigning i deres udlandsinvesteringer. Den indiske regering har altid haft et tvetydigt syn på indiske firmaers investeringer i udlandet (Pedersen, 2006). På den ene side er det siden 1970'erne blevet fremhævet, at indiske udlandsinvesteringer kunne bidrage til at styrke vareeksporten, og den indiske stat har derfor på forskellig vis søgt at støtte sådanne investeringer. På den anden side har udlandsinvesteringer været betragtet som en udførsel af kapital, hvilket et fattigt land som Indien ikke havde råd til. Regeringen har især tilladt udlandsinvesteringer i perioder, hvor beholdningen af udenlandsk valuta har været tilstrækkelig set $\mathrm{i}$ forhold til de udestående fordringer. Af den grund har det især været i en periode i slutningen af 1970'erne og igen, i væsentlig større omfang, fra midten af 1990'erne, jf. figur 2, at indiske virksomheder har fået tilladelse til at investere udenlands. I dag er der således åbnet helt op for, at indiske virksomheder kan ekspandere internationalt, og de har fået lov til at søge international lånefinansiering til eksempelvis opk $\varnothing \mathrm{b}$ af udenlandske virksomheder. Oprindelig var indiske virksomheder mest aktive i andre udviklingslande, især i Afrika og Sydøstasien, men i de seneste år er der sket en drejning imod Europa og USA, og indiske virksomheder opkøber i dag regelmæssigt små eller mellemstore virksomheder på disse markeder, eller de foretager investeringer i nye aktiviteter. ${ }^{13}$ Alene i første halvdel af 2006 rapporterede den indiske presse om opkøb inden for medicinalvarer, vindmølleindustrien, den kemiske industri, software, elektronik og telekommunikationsudstyr og metalindustrien - foruden investeringer inden for olie- og gasudvinding i flere lande foretaget af sektorens store statsforetagender. ${ }^{14}$

Åbningen over for omverdenen har bevirket en stærk stigning i omfanget af direkte investeringer fra udlandets side i Indien op igennem 1990'erne. Tidligere var omfanget af udenlandske investeringer ganske begrænset, men fra midten af 1990 'erne voksede omfanget til et årligt niveau på omkring 2-3 mia. USD og efter år 2000 yderligere til 4-6 mia. USD årligt. ${ }^{15}$ Selv om det er en betragtelig vækst, er det dog ikke imponerende, specielt når man tager Indiens størrelse i betragtning, og den indiske regering har da også udtrykt ønske om væsentlig flere investeringer. Ønsket om investeringer skyldes dog ikke et behov for udenlandsk valuta, jf. igen figur 2 , og det indiske erhvervsliv har formentlig været ganske godt tilfreds med, at udenlandske virksomheder ikke i større omfang er trængt ind på det indiske marked. Ifølge tilgængelige oplysninger er det således lykkedes de indiske virksomheder at bibeholde deres stærke hjemlige position. ${ }^{16}$ Dette er det modsatte af, hvad man ser i mange andre lande, som har åbnet op for udenlandske investeringer. Sammenholder man det med den indiske udlandsekspansion, peger det på, at det indiske erhvervsliv har klaret sig usædvanlig godt under den $\emptyset$ konomiske globalisering.

Ser man på Indiens samlede situation er det også bemærkelsesværdigt, at det er lykkedes i så stort omfang at komme ud af den sårbare gældssituation, som 
1980'ernes låneoptagelser i udlandet havde afstedkommet. Et meget anvendt mål for $\varnothing$ konomisk sårbarhed over for internationale finansielle spekulationer består i at sammenholde omfanget af valutareserverne med størrelsen af den kortfristede gæld. ${ }^{17}$ Indiens sårbarhed er målt på denne måde blevet klart reduceret, idet den kortfristede gæld er blevet aftrappet, samtidig med at valutareserverne er skudt i vejret. De årlige afbetalinger på den samlede udlandsgæld har da også udgjort en stadig mindre del af eksportindtægterne, og gældens andel af nationalproduktet er blevet halveret, siden den toppede i 1992 (World Bank, 2006). Sammenholder man den større finansielle robusthed med den fortsatte statslige kontrol med de fleste kapitalbevægelser ud og ind af landet, bliver det lettere at forstå, hvorfor Indien ikke i væsentligt omfang blev ramt af den asiatiske finanskrise i 1997 og de $\varnothing$ konomiske sanktioner i forbindelse med atomsprængningerne i maj 1998. Indien blev selvfølgelig påvirket gennem en faldende eksport til de hårdt ramte sydøstasiatiske lande og en generel international afmatning, men den indiske nationalbank afbødede de direkte virkninger gennem st $\varnothing t t e o p k \emptyset b$ af den indiske valuta og gennem en mindre renteforh $\varnothing j$ else. Faldet i den økonomiske vækst i 1997-98, jf. figur 1, skyldtes da også i lige så høj grad en dårlig høst som de ugunstige internationale vilkår. ${ }^{18}$

Indiens succes med at $\emptyset \mathrm{ge}$ sin integration i den globale $\emptyset$ konomi og samtidig hermed reducere sin sårbarhed skyldes især to forhold, som meget godt afspejler den tvetydighed, som karakteriserer Indiens forhold til globaliseringen. Den største indiske succes har været den hurtigt voksende eksport af software og andre it-relaterede ydelser, der kan ses som eksempler på fremtidsrettede $\emptyset$ konomiske aktiviteter. De årlige nettoindtægter herfra er op gennem 1990'erne vokset eksponentielt, og nåede i 2005-06 op på godt 22 mia. USD. Samtidig har den største

Figur 2. Valutareserver og kortfristet gæld, 1970-2004

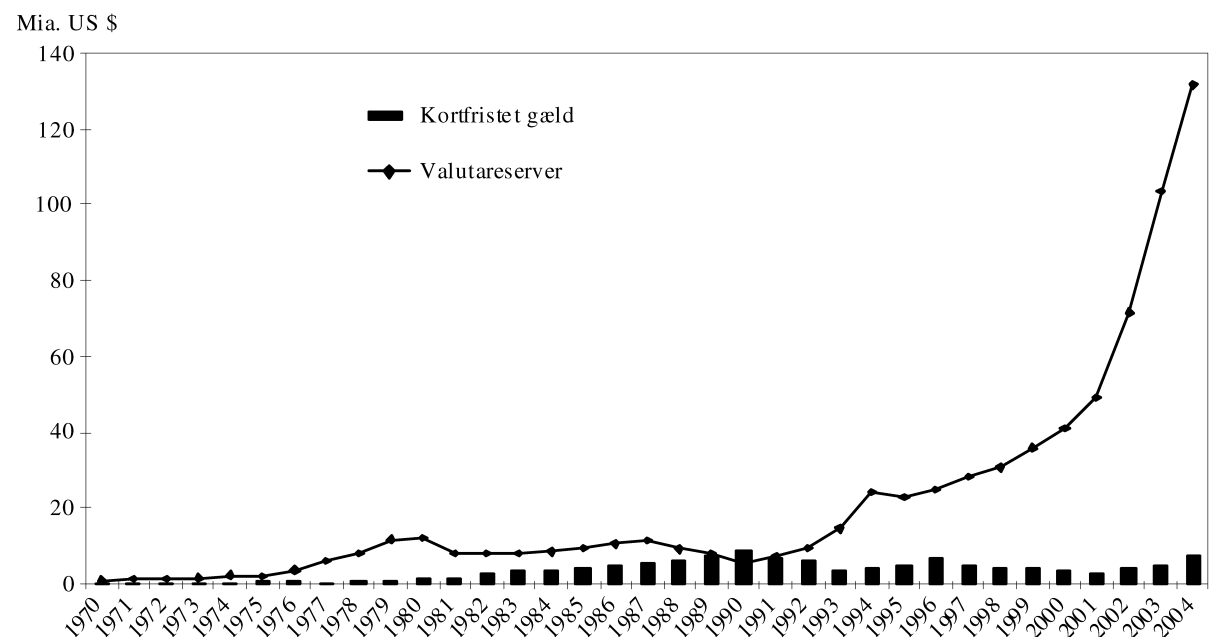

Kilde: World Bank (2006). 
kilde til udenlandsk valuta ved siden af den traditionelle vareeksport bestået i hjemsendelser af penge fra indiske gæstearbejdere i udlandet, hovedparten formentlig fra landene omkring Den Persiske Golf. Disse private hjemsendelser udgjorde i 2005-06 mere end 24 mia. USD, og de repræsenterer i stort omfang mere traditionelle økonomiske aktiviteter baseret på ufaglært arbejdskraft, som man traditionelt forbinder med udviklingslande. ${ }^{19}$

I en samlet vurdering af, hvordan Indien har klaret sig i forhold til den økonomiske globalisering, er det vigtigt at holde sig for øje, at landet har været - og stadig på mange områder er - en relativt marginal deltager $\mathrm{i}$ den internationale $\emptyset$ konomi. Dette illustreres bedst ved at se på Indiens andel af den globale handel. Både eksporten og importen er, som det kunne forventes, steget betydeligt efter åbningen af økonomien, men Indiens andel af den globale eksport er stadig meget begrænset. Efter at være faldet støt siden 1950'erne, stabiliseredes Indiens andel af verdens samlede vareeksport på et niveau af ca. 0,4 pct. i starten af 1980 'erne. Herefter steg andelen langsomt til 0,5 pct. i 1990 og videre til 0,75 pct. i 2003 (UNCTAD, 2005). Indiens andel af den globale handel er således steget med 50 pct. siden starten af 1990'erne, hvilket er bemærkelsesværdigt, men der er stadig tale om en yderst beskeden andel for et så stort land som Indien. I 2004 var den indiske eksport således blot på niveau med Danmarks. ${ }^{20}$ Man skal i vurderingen af den indiske eksport dog samtidig huske på, at den især består af industriprodukter fra hjemlige virksomheder, og ikke fra afdelinger af multinationale selskaber, som man ser det mange andre steder i verden. Indien har således alt $\mathrm{i}$ alt klaret sig ganske godt, når man udelukkende ser på de økonomiske aspekter af globaliseringen.

\section{Globaliseringens bagside}

Som omtalt er der løbende pågået en intens debat i Indien omkring den nye $\emptyset$ konomiske strategi og globaliseringens virkninger i det indiske samfund. Der findes derfor en righoldig litteratur, som i mere eller mindre skarpe vendinger peger på problematiske sider ved Indiens deltagelse i globaliseringen og ved den nye $\emptyset$ konomiske politik. Kritikken kan lidt forenklet opdeles i to lejre. ${ }^{21}$ Den ene lejr består af dem, som bebrejder de skiftende indiske regeringer, at de økonomiske reformer ikke har været tilstrækkelig omfattende og dybtgående. Her peges der blandt andet på manglende privatiseringer af statsvirksomheder, på fraværet af arbejdsmarkedsreformer og på de fortsat store underskud på de offentlige budgetter. ${ }^{22}$ Den anden lejr består af dem, der især fokuserer på udviklingens sociale side og den betydning, reformerne og åbningen over for den internationale økonomi har haft for den brede befolkning, specielt de fattigste grupper. Her peges der på, at den $\emptyset$ konomiske vækst ikke i nævneværdigt omfang har betydet en forøget beskæftigelse, og at de $\mathrm{i}$ forvejen store skævheder $\mathrm{i}$ det indiske samfund er blevet yderligere uddybet siden 1991. Det gælder både forskellene mellem rig og fattig, mellem land og by samt meget tydeligt mellem forskellige regioner. Blandt disse kritikere finder man både tidligere økonomiske rådgivere for den indiske regering, økonomer tilknyttet den politiske venstrefløj, og den verdenskendte indiske Nobelpristager i økonomi Amartya Sen. ${ }^{23}$ Den sene- 
ste udgave af den alternative $\varnothing$ konomiske årsoversigt omhandler da netop også de mange skævvridninger, som efter de bidragydende forfatteres vurdering har været konsekvensen af de økonomiske reformer (Alternative Survey Group, 2005).

Spørgsmålet omkring udviklingen i fattigdommen har meget naturligt spillet en stor rolle i debatten omkring de mulige skyggesider af den økonomiske globalisering. Indien har en omfattende produktion af statistikker, som belyser spørgsmål med relevans for vurderingen af udviklingen i den absolutte fattigdom. Problemet har blot været, at metoden for indsamling af relevante data om befolkningens forbrugsmønster er blevet ændret siden 1993-94, hvorved det bliver vanskeligt at sammenligne med tidligere tal. Den omfattende (og til tider ophedede) debat, som har fulgt med fremkomsten af stadig flere oplysninger har ligefrem givet anledning til betegnelsen "The Great Indian Poverty Debate" (Deaton og Kozel, 2005). Ifølge de officielle tal for, hvor mange indere der lever under den fastlagte fattigdomsgrænse, har andelen af fattige både i byerne og på landet været støt faldende igennem de sidste 30 år. De første tal for slutningen af 1990'erne viste, at faldet var fortsat, også efter iværksættelsen af de økonomiske reformer, så andelen af fattige på dette tidspunkt var nået ned på godt 25 pct. af den samlede befolkning. Senere revisioner af tallene med henblik på at gøre dem sammenlignelige med tidligere oplysninger er imidlertid endt med væsentlig højere skønsmæssige andele. Ifølge én revision lever således omkring 35-40 pct. af befolkningen på landet under fattigdomsgrænsen, mens andelen i byerne ligger omkring 30 pct. $^{24}$

Ud af en samlet befolkning på mere end 1 milliard mennesker er det under alle omstændigheder rigtig mange mennesker. De indiske vælgere synes ifølge resultatet af parlamentsvalget i 2004 heller ikke, at de har mærket de store fordele ved globaliseringen. I hvert fald gik den siddende regeringskoalition til valg på baggrund af flotte økonomiske væksttal og under slagordet India Shining, men oppositionen under ledelse af Kongrespartiet gik til valg på løfter om at ville føre en politik, der gavnede den almindelige borger (Nayar, 2005). Til stor overraskelse for alle, der havde læst opinionsundersøgelserne før valget, blev det oppositionen, som løb af med sejren, blandt andet på grund af stor opslutning fra de fattige $\mathrm{i}$ byerne og fra landområderne. Hvorvidt det så vil lykkes den nye regering at rette op på nogle af de sociale skævheder, som har kendetegnet udviklingen siden 1990'ernes begyndelse, er tvivlsomt, men det er da interessant, at den nye regering hviler på et parlamentarisk grundlag, der indbefatter de indiske kommunistpartier, som har været nogle af liberaliseringspolitikkens mest hårdnakkede kritikere. Og de ser det netop som deres rolle at være dem, der retter op på nogle af de sociale skævheder, som er blevet forstærket gennem de seneste år. ${ }^{25}$

\section{To teoretiske perspektiver}

Den måde, Indien med betydelig succes har tacklet globaliseringen på, rejser flere interessante teoretiske problemstillinger. Jeg vil i denne sammenhæng fremhæve de udfordringer, som det indiske eksempel frembyder for to fremtrædende teoretiske bidrag inden for den nyere internationale udviklingsteoretiske debat. Det ene teoretiske perspektiv vedrører de udviklingspolitiske tiltag, som under 
betegnelsen Washington Consensus i toneangivende internationale kredse længe har været anset for at være de mest hensigtsmæssige for både de traditionelle udviklingslande og de såkaldte transitionslande, dvs. de tidligere østbloklande. Det andet teoretiske perspektiv udspringer af debatten omkring den såkaldte "udviklingsstat", som har været en toneangivende forklaring på flere af de østasiatiske landes $\varnothing$ konomiske udviklingssucces. Denne debat har blandt andet fokuseret på etableringen af udviklingsstrategiske beslutningsstrukturer, især i statens samspil med lokale industrialister, med embedded autonomy som et centralt udtryk for karakteren af dette samarbejde.

Washington Consensus var den betegnelse, som den amerikanske $\emptyset$ konom John Williamson anvendte om det sæt af økonomiske politikker, som de vigtigste internationale, men Washington-baserede, organisationer (Verdensbanken, Den Internationale Valutafond, Den Inter-Amerikanske Udviklingsbank) efter hans opfattelse var blevet enige om som den rette vej til økonomisk fremgang for de latinamerikanske lande (Williamson, 1993). Det samlede sæt af politikker omfattede ti punkter, hvor af nogle af de vigtigste var statsfinansiel "disciplin", liberalisering af udenrigshandelen, privatisering af statsvirksomheder, generel deregulering og åbenhed over for udenlandske investeringer. Det interessante er naturligvis, at Indien nok har gennemført nogle af disse tiltag, eksempelvis liberalisering af udenrigshandelen og åbenhed over for udenlandske investeringer, men at nogle af de væsentligste punkter slet ikke er blevet gennemført. Først og fremmest har skiftende indiske regeringer ikke fået bugt med det store statsfinansielle underskud, man har heller ikke i praksis gennemført privatiseringer, og den indiske økonomi har bibeholdt mange statslige reguleringer, om end der er sket en væsentlig deregulering. Indiens $\emptyset$ konomiske succes udgør derfor en betydelig udfordring til det internationale establishments forståelse af de "rigtige" udviklingspolitikker. Williamson har selv i en analyse af den indiske reformproces bemærket dette, men frem for at erkende, at det udgør et problem for forståelsen af den "rigtige" udviklingspolitik, vælger han at fokusere på de allerede gennemførte reformtiltag og på den gradvise måde, de er blevet gennemført på (Williamson og Zagha, 2002).

Udviklingsstatsdiskussionen har som anført især beskæftiget sig med karakteren af det udviklingspolitiske beslutningssystem, snarere end de resulterende gennemførte politikker. Et centralt bidrag til diskussionen har været den amerikanske sociolog Peter Evans' bud på, hvad de karakteristiske træk ved en udviklingsstat er. Ifølge Evans beror eksempelvis Koreas økonomiske succes på, at det dér er lykkedes at etablere et frugtbart samarbejde mellem stat og erhversliv, som han betegner som embedded autonomy (Evans, 1995). Udtrykket henviser til, at en vellykket økonomisk transformation kræver, at staten på den ene side er autonom i forhold til erhvervslivet og andre vigtige samfundsgrupper, hvilket et stærkt og veluddannet weberiansk bureaukrati kan medvirke til. På den anden side kræver det, at staten herudover har tætte, gerne institutionaliserede, forbindelser (embeddedness) til det selv samme erhvervsliv, fordi staten kun derigennem kan opnå den konkrete og praktiske viden, som er nødvendig for at kunne udforme politikker, der kan lykkes i praksis. På baggrund af 
disse overvejelser burde den lykkelige kombination af embeddedness og autonomy - eller en tilnærmelse hertil - således kunne genfindes i lande med succesrig $\emptyset$ konomisk udvikling. Evans hæfter sig dog også ved, at den koreanske stat ganske vist har støttet sin private sektor, men at den også på afgørende punkter har disciplineret de private virksomheder gennem eksempelvis strenge krav om eksportorientering med videre.

Også i dette teoretiske lys frembyder Indien lidt af et paradoks. En af de cases, som Evans analyserede, var netop Indien, og hans konklusion var, lidt forenklet, at den indiske stat så at sige havde for meget autonomi (og bureaukrati) og for lidt embeddedness (Evans, 1995:66-70). Evans' analyse henviser til perioden før 1990, men på den baggrund ville man ikke have forventet, at netop Indien ville klare sig så godt op igennem 1990'erne. Betragter man imidlertid forandringerne $\mathrm{i}$ forholdet imellem staten og det indiske erhvervsliv nøjere, er der ikke nogen tvivl om, at det klart har udviklet sig i retning af den type indbyrdes relationer, som ifølge Evans kendetegner udviklingsstater (Pedersen, 2002; Kohli, 2006). Der er dog mindst to tilføjelser til denne konklusion. Det ene er, at den indiske stat ikke i nævneværdigt omfang har søgt at disciplinere det indiske erhvervsliv, eksempelvis ved at påbyde forskellige aktiviteter, men primært har søgt at tilskynde til nye aktiviteter, eksempelvis til eksport af software eller til forskning og udvikling. Det andet er, at den indiske stats forbindelser til erhvervslivet ikke har været eksklusive, i den forstand at der i løbet af 1990'erne er blevet opbygget delvist institutionaliserede samarbejdsrelationer til en lang række andre samfundsgrupper. Interessant i relation til globaliseringens betydning er, at den forstærkede indsats i forhandlingerne inden for WTO har været ledsaget af et meget tæt samarbejde med både erhvervsliv og forskellige typer af ekstern ekspertise og interessegrupper inden for de forskellige forhandlingstemaer. Der er her tale om ekspertise indhentet fra både private og offentlige forskningsinstitutioner og fra forskningsintensive private firmaer. Disse afvigelser fra den teoretiske udviklingsstatsmodel, som Evans har udviklet, kan muligvis tolkes som et tegn på, at den form for embedded autonomy, som vil være påkrævet for at sikre økonomisk vækst inden for en både globaliseret og mere vidensintensiv $\emptyset$ konomi, nødvendigvis må være anderledes og mindre autoritær end den, som i en anden kontekst var med til at sikrede Korea så spektakulær økonomisk fremgang.

\section{Afslutning}

Modsat mange udviklingslande på samme indkomstniveau har Indien undgået at blive økonomisk marginaliseret af globaliseringen. Landet har generelt opnået økonomiske fremskridt i de seneste år, også på vidensintensive og teknologisk avancerede områder, som normalt ligger uden for fattige landes formåen. Baggrunden hertil må ses som en kombination af dels de opnåede resultater fra den tidligere udviklingsstrategi, dels de nyorienteringer, som især efter 1991 har præget den indiske regerings udviklingspolitik. Nyorienteringer, som på bemærkelsesværdig vis er blevet opretholdt under skiftende regeringskonstellationer. Det er dog ikke på alle punkter, at der er sket fremskridt, og Indien indtager stadig en 
meget beskeden plads i verdens $\varnothing$ konomien. Der er også stadig store og i visse henseender stigende sociale og til dels politiske problemer, som kan henføres til den økonomiske globalisering. Det er derfor ikke en given sag, at Indiens nuværende fremmarch vil fortsætte ufortrødent. I et udviklingsteoretisk lys har udviklingen i Indien også været både interessant og relevant for andre udviklingslande, og det vil den formentlig fortsætte med at være, ikke mindst fordi udformningen af de politiske svar på globaliseringens udfordringer i så høj grad har været præget af lokale kræfter og kun i mindre grad af internationale politiske og teoretiske strømninger.

\section{Noter}

1. Artiklen bygger i betydeligt omfang på et større - endnu upubliceret - manuskript, som sammenligner Indiens og Brasiliens reaktioner på globaliseringens udfordringer.

2. For et overblik over den finansielle globalisering, se Held et al. (1999:201ff.) og O'Brien og Williams (2004:224ff.).

3. I en periode fra midten af 1990 'erne og fremefter blev der endda udgivet to konkurrerende alternative $\varnothing$ konomiske oversigter. Den ene blev udgivet af Alternative Survey Group; den anden af Delhi Science Forum.

4. Disse betegnelser bruges her for nemheds skyld, men det skal understreges, at indisk politiks kompleksitet ikke så let lader sig indfange i en enkelt højre-venstredimension.

5. Et fors $\emptyset \mathrm{g}$ på en mere omfattende forklaring på introduktionen af de $\emptyset$ konomiske reformer og på deres videreførelse findes i Pedersen (2000).

6. Den indiske finansavis Economic Times (23.2.2001) har en nyttig oversigt over de første ti års reformer, og den indiske nationalbanks årssrapport for 2001-02 indeholder en gennemgang og vurdering af reformpolitikkens første ti år (RBI, 2003).

7. Data herom findes på WTO's hjemmeside: www.wto.org. Se også Degnbol-Martinussen (2002:65-69).

8. Der er naturligvis en lang og stadig igangværende debat om emnet, hvor tilhængerne af reformerne hævder, at de netop har bevirket en opretholdelse af 1980'ernes vækstniveau, som ellers ville være brudt sammen. Kritikerne bestrider selvfølgelig dette.

9. Sektoropdelte vækstrater kan ses i Kohli (2006).

10. If $\varnothing$ lge mine egne beregninger er andelen $\emptyset$ get fra godt 4 pct. til godt 6 pct., hvilket ikke er så dårligt endda, selv sammenlignet med udviklede lande. Beregningerne omfatter kun almindelige fremstillingsvirksomheder og inddrager ikke software-industrien og andre vidensintensive serviceindustrier.

11. Der er to kilder til disse virksomhedsoplysninger. Den ene vedrører virksomheder med særlige forskningsenheder, der er registreret af de indiske myndigheder. Den anden stammer fra regnskabsoplysninger fra de virksomheder, som indgår i Reserve Bank of Indias regelmæssige analyser. Begge virksomhedsgrupper udviser samme tendens.

12. Det er naturligvis vanskeligt at opgøre omfanget af disse ændringer. Vurderingen bygger blandt andet på casehistorier fra indisk og international presse, på indiske virksomheders placering på diverse internationale ranglister, samt på egne iagttagelser. Det fremhæves ofte, at indiske virksomheder er karakteriseret af meget dygtig ledelse.

13. Beholdningen af indiske direkte investeringer i udlandet var indtil marts 2005 ifølge den seneste opgørelse fra Reserve Bank of India vokset til omkring en fjerdedel af beholdningen af udenlandske investeringer i Indien (RBI, 2006). 
14. Oplysningerne stammer fra den indiske finansavis, The Economic Times (http:// economictimes.indiatimes.com).

15. De nøjagtige tal kan findes på Reserve Bank of Indias hjemmeside (www.rbi.org.in).

16. If $\varnothing \operatorname{lge}$ en opgørelse fra Centre for Monitoring the Indian Economy (www.cmie.com) ejede udenlandsk virksomheder i $199711-12$ pct. af de ca. 7.000 største aktieselskabers aktiver, hvilket var et lille fald i forhold til 1991. Opgørelsen er i dag fjernet fra hjemmesiden. Ifølge mine egen beregninger på basis af Reserve Bank of Indias virksomhedsoplysninger tegner udenlandske virksomheder sig for under 25 pct. af både produktion og aktiekapital blandt omkring 2.000 af de større virksomheder (www.rbi.org.in).

17. Kortfristet gæld er gæld med en løbetid på under ét år.

18. En gennemgang af krisens virkninger på den indiske $\emptyset$ konomi og nationalbankens indgreb findes i RBI (1997-98, 1998-99).

19. Den indiske betalingsbalancestatistik kan findes på www.rbi.org.in.

20. Danmark var nr. 29 og Indien nr. 30 på WTO's liste over verdens førende eksportlande opgjort i International trade statistics 2005, Table I.5 (www.wto.org).

21. Jeg undlader her helt at komme ind på kritikken af de miljømæssige konsekvenser, som udgør en tredje lejr.

22. Denne kritik kommer blandt andet tydeligt frem i Joshi og Little (1997), i flere bidrag i Lal (1999) samt i indlæggene fra T.N. Srinivasan og Anne Krueger i Krueger (2002). Det er også synspunkter, som præger de løbende kommentarer fra den Internationale Valutafond til udviklingen i Indien.

23. Bhaduri og Nayyar, 1996; Chandrasekhar og Ghosh, 2002; Drèze og Sen, 2002. Nayyar er tidligere toprådgiver for den indiske regering.

24. Tallene er figurligt afbildet i Drèze and Sen (2002:325).

25. Det vigtigste parti er Communist Party of India (Marxist). Se evt. dets hjemmeside: http://www.cpim.org.

\section{Litteratur}

Alternative Survey Group (2005). Alternative Economic Survey, India 2004-2005. Disequalising Growth, New Delhi: Daanish Books.

Bhaduri, Amit and Deepak Nayyar (1996). The Intelligent Person's Guide to Liberalization, New Delhi: Penguin Books.

Chandrasekhar, C.P. and Jayati Ghosh (2002). The Market That Failed. A Decade of Neoliberal Economic Reforms in India, New Delhi: LeftWord Books.

Deaton, Angus and Valerie Kozel (eds.) (2005). The Great Indian Poverty Debate, Delhi: Macmillan India Ltd.

Degnbol-Martinussen, John (2001). Policies, Institutions and Industrial Development. Coping with Liberalisation and International Competition in India, New Delhi: Sage.

Degnbol-Martinussen, John (2002).’External Constraints on Policy-Making and Industrial Development in India", European Journal of Development Research, Vol. 14, No. 1, pp. 47-76.

Drèze, Jean and Amartya Sen (2002). India. Development and Participation, New Delhi: Oxford University Press.

Evans, Peter (1995). Embedded Autonomy. States and Industrial Transformation, Princeton: Princeton University Press.

Forbes, Naushad (2002). "Doing Business in India: What has Liberalization Changed?, pp. 129-167 in Anne O. Kruger (ed.), Economic Policy Reforms and the Indian Economy, New Delhi: Oxford University Press. 
Ghoshal, Sumantra, Gita Piramal and Sudeep Budhiraja (2001). World Class in India. A Casebook of Companies in Transformation, New Delhi: Penguin Books.

Government of India (1991). New Industrial Policy 1991, New Delhi.

Harriss, John (1987). "The State in Retreat? Why has India Experienced Such Halfhearted 'Liberalisation' in the 1980s?", IDS Bulletin, Vol. 18, No. 4, pp. 31-38.

Held, David, Anthony McGrew, David Goldblatt and Jonathan Perraton (1999). Global Transformations. Politics, Economics, Culture, Cambridge: Polity Press.

Hoogvelt, Ankie (1997). Globalisation and the Postcolonial world. The New Political Economy of Development, London: Macmillan.

Joshi, Vijay and I.M.D. Little (1997). "India. Reform on Hold", Asian Development Review, Vol. 15, No. 2, pp. 1-42.

Kohli, Atul (1989). "Politics of Economic Liberalization in India", World Development, Vol. 17, No. 3, pp. 305-328.

Kohli, Atul (2006). "Politics of Economic Growth in India, 1980-2005", Economic and Political Weekly, Part I-II, XLI:13, pp. 1251-1259; XLI:14, pp. 1361-1370.

Kruger, Anne O. (ed.) (2002). Economic Policy Reforms and the Indian Economy, New Delhi: Oxford University Press.

Lal, Deepak (1999). Unfinished Business. India in the World Economy, New Delhi: Oxford University Press.

Marathe, Sharad S. (1986), Regulation and Development. The Indian Policy Experience of Controls Over Industry, New Delhi: Sage.

Manor, James (1995). "The Political Sustainability of Economic Liberalization in India", pp. 339-363 in Robert Cassen and Vijay Joshi (eds.), India. The Future of Economic Reform, New Delhi: Oxford University Press.

McDowell, Stephen D. (1994). "India, the LDCs, and GATT negotiations on Trade and Investment in Services", pp. 497-510 in Richard Stubbs and Geoffrey R.D. Underhill (eds.), Political Economy and the Changing Global Order, London: Macmillan.

Nayar, Baldev Raj (2005). "India in 2004. Regime Change in a Divided Democracy", Asian Survey, Vol. 45, No. 1, pp. 71-82.

O'Brien, Robert and Marc Williams (2004). Global Political Economy. Evolution and Dynamics, London: Palgrave.

OECD (1996). The Knowledge-Based Economy, Paris (OCDE/GD(96)102).

Patel, I.G. (1987). "On Taking India into the Twenty-First Century (New Economic Policy in India)", Modern Asian Studies, Vol. 21, No. 2, pp. 209-231.

Pedersen, Jørgen Dige (2000). "Explaining Economic Liberalization in India: State and Society Perspectives", World Development, Vol. 28, No. 2, pp. 265-282.

Pedersen, Jørgen Dige (2002). "Economic Globalization and the Fate of the Developmental State: India and Brazil in the 1990s", Paper presented at XIII NOPSA Conference, Aalborg, August 15-17, 25p.

Pedersen, Jørgen Dige (2006). 'The Second Wave of Indian Investments Abroad', Paper presented at the 19th ECMSAS Conference in Leiden, June, Institut for Statskundskab, 31pp.

Pérez, Carlota (2001). "Technological change and opportunities for development as a moving target", CEPAL Review 75, pp. 109-130.

Reserve Bank of India (RBI) (1997-98, 1998-99). Annual Report, Mumbai.

Reserve Bank of India (RBI) (2003). Report on Currency and Finance 2001-02, Mumbai.

Reserve Bank of India (RBI) (2006). Report on Foreign Exchange Reserves, Mumbai.

UNCTAD (2005). Handbook of Statistics (online: http://www.unctad.org).

Wadhva, Charan (1994). Economic Reforms in India and the Market Economy, New Delhi: Allied Publishers.

Williamson, John (1993). "Democracy and the "Washington Consensus"”, World development, Vol. 21, No. 8, pp. 1329-1336. 
Williamson, John and Roberto Zagha (2002). "From the Hindu Rate of Growth to the Hindu Rate of Reform", Working Paper No. 144, Stanford University, Center for Research on Economic Development and Policy Reform.

World Bank (2006). Global Development Finance 2006, Washington (CD ROM). 